\title{
PENGARUH JUMLAH BENIH PER LUBANG DAN JARAK TANAM SORGHUM MANIS (Sorghum bicolor (L.) Moench) TERHADAP PERFORMA VEGETATATIF PADA RATUN KETIGA
}

\section{The Effect of Number of Seeds Per Hole and Plant Spacing on Sweet Sorghum (Sorghum bicolor (L.) Moench) Vegetative Performance at the third Ratoon}

\author{
Annisa Nurhaliza, Liman, Agung Kusuma Wijaya, dan Muhtarudin \\ Departement of Animal Husbandry, Faculty of Agriculture, University of Lampung \\ Jl. Prof. Dr. Soemantri Brojonegoro No.1 Gedung Meneng Bandar Lampung 35145 \\ e-mail : halizaniza211997@gmail.com
}

\begin{abstract}
This research aimed to know the effect of number of seeds per hole and plant spacing on the vegetatitive performance of forage sorghum. This research was conducted on July--September 2019 at Integrated Field Laboratory and Animal Nutrition and Feed Laboratory, Department of Animal Husbandry, Faculty of Agriculture, University of Lampung. The study was done based on Factorial Randomized Block Design. The first treatment consisted of 3 number of seeds which was one, two, and three seeds and grouped by different land contours. The second treatment consisted of plant spacing which was $50 \mathrm{x} 30$ $\mathrm{cm}, 66,6 \times 30 \mathrm{~cm}$ and $100 \times 30 \mathrm{~cm}$. The data obtained were analyzed using variance analysis and continued by using Duncan Multiple Range Test at $5 \%$ level of significance. The results showed that there was no interaction $(\mathrm{P}>0,05)$ between the number of seeds per hole and plant spacing on fresh matter production, number of tillers, proportion of leaves stems, plant height, and number of leaves of sorghum forage at the third ratoon. The number of seeds per hole significantly affected $(\mathrm{P}<0.05)$ on plant height, but did not significantly affect the fresh matter production, number of tillers, proportion of leaf stems, plant height, and number of leaves sorghum forage. The result also showed that plant spacing did not significantly affected $(\mathrm{P}>0,05)$ on fresh matter production, number of tillers, proportion of leaf stems, and number of leaves of sorghum forage at the third ratoon.
\end{abstract}

Keywords: number of seeds per hole, plant spacing, Sweet sorghum, third ratoon, vegetative performance

\begin{abstract}
ABSTRAK
Penelitian ini bertujuan untuk mengetahui pengaruh jumlah benih per lubang dan jarak tanam terhadap performa vegetatif hijauan sorghum. Penelitian ini dilaksanakan pada Juli--September 2019 di Laboratorium Lapang Terpadu dan Laboratorium Nutrisi dan Makanan Ternak, Jurusan Peternakan, Fakultas Pertanian, Universitas Lampung. Penelitian ini menggunakan Rancangan Acak Kelompok Faktorial (RAKF) dua faktor. Faktor pertama berupa jumlah benih per lubang yang meliputi satu, dua, dan tiga benih dan dikelompokkan berdasarkan kontur tanah yang berbeda. Faktor kedua berupa jarak tanam yang meliputi $50 \times 30 \mathrm{~cm}, 66,6 \times 30$, dan $100 \times 30 \mathrm{~cm}$. Data yang diperoleh dianalisis ragam pada taraf nyata serta dilanjutkan dengan uji lanjut Duncan 5\%. Hasil penelitian menunjukkan bahwa tidak terdapat interaksi $(\mathrm{P}>0,05)$ antara jumlah benih per lubang dan jarak tanam terhadap produksi segar, jumlah anakan, proporsi batang daun, tinggi tanaman, dan jumlah daun hijauan sorghum pada ratun ketiga. Jumlah benih per lubang berpengaruh nyata $(\mathrm{P}<0,05)$ terhadap tinggi tanaman, namun tidak berpengaruh nyata terhadap produksi segar, jumlah anakan, proporsi batang dan daun, dan jumlah daun. Hasil penelitian juga menunjukkan bahwa jarak tanam tidak berpengaruh nyata $(P>0,05)$ terhadap produksi segar, jumlah anakan, proporsi batang daun, tinggi tanaman, dan jumlah daun hijauan sorghum ratun ketiga.
\end{abstract}

Kata kunci: Jumlah benih per lubang, Jarak tanam, Sorghum manis, Ratun ketiga, Performa vegetatif 


\section{PENDAHULUAN}

\begin{abstract}
Sorghum (Sorghum bicolor (L.) Moench) merupakan tanaman serealia yang potensial untuk dibudidayakan dan dikembangkan sebagai pakan ruminansia, khususnya pada daerah-daerah marginal dan kering di Indonesia. Sorghum mempunyai daya adaptasi agroekologi yang luas, tahan terhadap kekeringan, produksi tinggi, serta lebih tahan terhadap hama dan penyakit
\end{abstract}

Sorghum sangat potensial karena daun dan batangnya dapat dijadikan campuran ransum ternak. Selain potensial untuk dijadikan sumber pangan alternatif dan sumber pakan ternak, sorghum juga dapat dijadikan sumber energi alternatif, terutama sorghum manis karena sorghum manis memiliki kandungan pati yang tinggi.

Budidaya sorghum di Indonesia masih belum intensif dilakukan oleh masyarakat Indonesia, padahal potensinya sangat baik untuk memenuhi kebutuhan pangan ataupun pakan ternak yang masih didominasi oleh pakan impor.

Oleh karena itu, untuk dapat meningkatkan produksi sorghum upaya yang dapat dilakukan adalah dengan memperbaiki cara budidaya, antara lain pengaturan jumlah benih per lubang tanam dan pengaturan jarak tanam sehinga dapat meningkatkan populasi tanaman. Pemakaian benih per lubang tanam berpengaruh terhadap pertumbuhan karena secara langsung berhadapan dengan kompetisi dalam memperebutkan faktor tumbuh (air, cahaya matahari, dan unsur hara) antar tanaman dalam satu rumpun. Penggunaan jumlah benih yang tepat akan memberikan hasil akhir yang baik, selain itu lebih efisien dalam penggunaan lahan (Harjadi, 2002).

Upaya lain dalam peningkatan produksi sorghum adalah melalui pemanfaatan sistem ratun. Ratun adalah salah satu cara untuk meningkatkan hasil per satuan luas lahan dan per satuan waktu. Tanaman ratun tidak memerlukan benih, cukup menggunakan regenerasi tunas, dan merupakan sarana yang berguna untuk memulai budidaya pada kelembaban (20--40 \%) tanah terbatas. Menurut Puspita et al. (2012), kelebihan tanaman sorghum (ratun) adalah umurnya relatif lebih pendek, kebutuhan air lebih sedikit, biaya produksi lebih rendah karena penghematan dalam pengolahan tanah, penggunaan bibit, kemurnian genetik lebih terpelihara dan hasil panen tidak berbeda jauh dengan tanaman utama.
Berdasarkan hal tersebut, perlu dilakukan penelitian mengenai pengaruh jumlah benih per lubang dan jarak tanam sorghum manis (Sorghum bicolor (L.) Moench) terhadap performa vegetatif pada ratun ketiga.

\section{MATERI DAN METODE}

\section{Waktu dan Tempat}

Penelitian ini dilaksanakan pada JuliSeptember 2019 yang bertempat di Laboratorium Lapang Terpadu serta Laboratorium Nutrisi dan Makanan Ternak Jurusan Peternakan, Fakultas Pertanian, Universitas Lampung.

\section{Bahan dan Alat}

Bahan-bahan yang digunakan pada penelitian ini berupa benih sorghum spesies Sorghum bicolor (L.) Moench varietas Numbu (diperoleh dari PT. Andini), pupuk kandang kotoran sapi (diperoleh dari kandang Jurusan Peternakan), abu, kapur dolomit, effective microorganisms 4 (EM-4), pupuk anorganik (Urea, TSP, dan $\mathrm{KCl}$ ) (diperoleh dari toko pertanian), dan air sumur.

Alat yang digunakan dalam penelitian ini adalah lahan seluas $200 \mathrm{~m}^{2}$, cangkul, golok, sabit, tali rafia, rol meter, sekop, timbangan gantung, terpal, kantong plastik (trash bag), selang, kamera, dan alat tulis.

\section{Metode}

Penelitian ini menggunakan pola faktorial $3 \times 3$ dengan metode rancangan acak kelompok (RAK) pola faktorial yang terdiri dua faktor perlakuan yaitu faktor jumlah benih per lubang dan faktor jarak tanam dan dikelompokkan berdasarkan kontur tanah yang berbeda. Faktor pertama jumlah benih per lubang (B) yaitu satu (B1), dua (B2), dan tiga (B3) benih per lubang. Faktor kedua jarak tanam (J) yaitu $50 \times 30 \mathrm{~cm}(\mathrm{~J} 1), 66,6 \times 30 \mathrm{~cm}$ (J2), dan $100 \times 30 \mathrm{~cm}(\mathrm{~J} 3)$. Setiap unit perlakuan percobaan berupa petak berukuran $2 \mathrm{~m}$ x $1,5 \mathrm{~m}$ dengan 9 kombinasi perlakuan dengan 3 ulangan maka terdapat 27 unit percobaan.

Pelaksanaan penelitian ini meliputi kegiatan: pemupukan, pemeliharaan, dan pemanenan pada umur 50 hari. Beberapa variabel yang diamati pada penelitian meliputi : produksi segar, jumlah anakan, proporsi batang dan daun, tinggi tanaman, dan jumlah daun.

Data yang diperoleh, dianalisis dengan sidik ragam (ANOVA). Jika perlakuan menunjukkan pengaruh nyata $(\mathrm{P}<0,05)$, maka analisis dilakukan dengan uji Duncan's Multiple Range Test (DMRT) $5 \%$. 


\section{HASIL DAN PEMBAHASAN}

Pengaruh Perlakuan Jumlah Benih per Lubang dan Jarak Tanam Hijauan Sorghum terhadap Produksi Segar pada Ratun Ketiga

Hasil penelitian tidak terjadi interaksi $(\mathrm{P}>0.05)$ antara perlakuan jumlah benih per lubang dan jarak tanam. Selain itu, perlakuan jumlah benih per lubang dan jarak tanam tidak berpengaruh nyata $(\mathrm{P}>0,05)$ terhadap produksi segar hijauan sorghum pada ratun ketiga. Ratarata produksi segar hijauan sorghum pada ratun ketiga dapat dilihat pada Tabel 1. Berdasarkan Tabel 1 dapat dilihat bahwa rata-rata produksi segar hijauan sorghum pada benih satu yaitu 26,63 ton/ha, selanjutnya pada benih dua yaitu 26,97 ton/ha, dan pada benih tiga yaitu 27,91 ton/ha. Hal ini diduga perlakuan tiga benih per lubang yang lebih banyak menghasilkan produksi segar tertinggi. Menurut Setyati (2002) penentuan jumlah tanaman per lubang tanam erat sekali hubungannya dengan tingkat populasi tanaman. Ditambahkan oleh Muyassir (2012) bahwa semakin banyak jumlah bibit per lubang tanam cenderung meningkatkan kompetitif antara tanaman dalam satu rumpun dan rumpun lainnya terhadap cahaya, ruang, dan unsur hara, sehingga mempengaruhi pertumbuhan dan produksi.

Tabel 1. Rata-rata produksi segar hijauan sorghum pada ratun ketiga

\begin{tabular}{|c|c|c|c|c|}
\hline \multirow{2}{*}{ Perlakuan 2} & \multicolumn{3}{|c|}{ Perlakuan 1} & \multirow{2}{*}{ Rata-rata } \\
\hline & B1 & B2 & B3 & \\
\hline & & --(ton/ha)- & - & --------------- \\
\hline $\mathrm{J} 1$ & 27,13 & 32,07 & 26,47 & $28,56 \pm 3,06$ \\
\hline $\mathrm{J} 2$ & 25,94 & 24,91 & 29,79 & $26,88 \pm 2,57$ \\
\hline $\mathrm{J} 3$ & 26,81 & 23,95 & 27,47 & $26,08 \pm 1,88$ \\
\hline Rata-rata & $26,63 \pm 0,61$ & $26,97 \pm 4,44$ & $27,91 \pm 1,71$ & \\
\hline
\end{tabular}

Keterangan:

Tidak berpengaruh nyata $(\mathrm{P}>0,05)$

$\mathrm{B} 1$ : benih 1 per lubang tanam

B2: benih 2 per lubang tanam

B3: benih 3 per lubang tanam

$\mathrm{J} 1$ : jarak tanam $50 \times 30 \mathrm{~cm}$

$\mathrm{J} 2$ : jarak tanam $66,6 \times 30 \mathrm{~cm}$

J3: jarak tanam 100x30 cm

Produksi segar tertinggi terdapat pada jarak tanam dua yaitu 30,38 ton/ha. Hal ini diduga bahwa jarak tanam yang lebar dengan ruang tumbuh yang lebar keberadaan unsur hara, air, dan cahaya sangat tinggi, sehingga diperoleh produksi tanaman yang optimal. Menurut Irfan (1999), jarak tanam yang terlalu lebar mengurangi jumlah populasi tanaman dan juga menyebabkan berkurangnya pemanfaataan cahaya matahari, dan unsur hara akan hilang karena penguapan. Pada kondisi seperti ini kemungkinan terjadinya persaingan semakin besar dalam hal mendapatkan faktorfaktor tumbuh $\left(\mathrm{CO}_{2}\right.$, cahaya, air, dan unsur hara).

Rataan produksi segar tanaman sorghum varietas Numbu pada penelitian ini berkisar 26,63--28,56 ton/ha. Nilai ini lebih rendah dari yang diperoleh Lestari (2019) bahwa produksi segar varietas Numbu yang diperoleh yaitu 54,76--75,28 ton/ha dan lebih rendah juga dari ysng diperoleh (Utami, 2019) yaitu 29,43--34,36 ton/ha. Hal tersebut membuktikan bahwa semakin sering diratun semakin rendah prduksi yang dihasilkan.
Kondisi cuaca pada saat penelitian yaitu panas atau kemarau, namun terjadi beberapa kali hujan. Tanaman yang mempunyai pertumbuhan yang baik akan mengandung hampir $90 \%$ air pada jaringannya. Banyaknya air dan ketersediannya akan mempengaruhi aktivitas penyerapan hara oleh akar tanaman, sehingga mempengaruhi perkembangan vegetatif tanaman yang juga akan meningkatkan berat tanaman. Hal ini menunjukan bahwa air dan tingkat produksi sangat erat hubungannya. Air dan unsur hara diserap oleh akar tanaman yang akan ditanslokasikan ke bagian tajuk tanaman.

\section{Pengaruh Perlakuan Jumlah Benih per Lubang dan Jarak Tanam Hijauan Sorghum terhadap Jumlah Anakan pada Ratun Ketiga}

Berdasarkan hasil analisis ragam pada menunjukkan tidak terjadi interaksi $(\mathrm{P}>0,05)$ antara perlakuan jumlah benih per lubang dan jarak tanam. Perlakuan jumlah 
benih per lubang dan jarak tanam tidak berpengaruh nyata $(\mathrm{P}>0,05)$ terhadap jumlah anakan hijauan sorghum pada ratun ketiga. Rata-rata jumlah anakan hijauan sorghum pada ratun ketiga dapat dilihat pada Tabel 2.

Berdasarkan Tabel 2 menunjukkan hasil tertinggi jumlah anakan terdapat pada perlakuan jumlah tiga benih per lubang yaitu 4,27 batang/tanaman. Hasil penelitian yang dilakukan Tambunan et al. (2018) menyatakan bahwa penanaman jumlah tiga benih per lubang menghasilkan produksi tertinggi jumlah anakan padi sawah dibandingkan penggunaan jumlah satu dan dua benih. Hal ini menunjukkan semakin banyak jumlah benih per lubang tanam maka akan menghasilkan jumlah anakan yang lebih banyak.

Tabel 2. Rata-rata jumlah anakan hijauan sorghum pada ratun ketiga

\begin{tabular}{|c|c|c|c|c|}
\hline \multirow{2}{*}{ Perlakuan } & \multicolumn{3}{|c|}{ Perlakuan 1} & \multirow{2}{*}{ Rata-rata } \\
\hline & B1 & B2 & B3 & \\
\hline 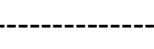 & - & atang/tanan & ----------- & ----------- \\
\hline $\mathrm{J} 1$ & 1,80 & 2,82 & 3,56 & $2,62 \pm 0,75$ \\
\hline $\mathrm{J} 2$ & 2,22 & 3,79 & 3,75 & $3,63 \pm 0,85$ \\
\hline $\mathrm{J} 3$ & 3,07 & 3,78 & 4,83 & $4,28 \pm 1,51$ \\
\hline Rata-rata & $2,36 \pm 0,65$ & $3,46 \pm 0,56$ & $4,27 \pm 0,69$ & \\
\hline
\end{tabular}

Keterangan:

Tidak berpengaruh nyata $(\mathrm{P}>0,05)$

$\mathrm{B} 1$ : benih 1 per lubang tanam

B2: benih 2 per lubang tanam

B3: benih 3 per lubang tanam

Perlakuan jarak tanam terhadap jumlah anakan tertinggi didapat pada jarak tanam tiga yaitu 4,28 batang/tanaman. Hal ini diduga bahwa semakin lebar jarak tanam jumlah anakan produktif semakin banyak dibandingkan jarak tanam yang sempit. Masdar et al. (2006) menyatakan bahwa semakin rapat populasi tanaman, semakin sedikit jumlah anakan per rumpunnya, tanaman yang tumbuh pada jarak tanam rapat dapat mengakibatkan stres pada vigor sehingga perkembangan anakan terhambat. Ditambahkan oleh Husna (2010) bahwa jumlah anakan maksimum juga ditentukan oleh jarak tanam, sebab jarak tanam menentukan penyerapan radiasi matahari, hara, dan mineral.

Panjang pemotongan batang tanaman utama dapat mempengaruhi jumlah anakan, periode pertumbuhan, vigor ratun, dan hasil biji (Escalada dan Plucknett, 1975). Menurut Harrel et al. (2009), tinggi pemotongan batang tanaman utama juga dapat mempengaruhi jumlah anakan dan hasil biji. Pemotongan batang tanaman utama setinggi $3 \mathrm{~cm}$ dari permukaan tanah menghasilkan anakan lebih sedikit, sehingga persediaan makanan yang cukup dapat dimanfaatkan dengan baik, dibandingkan dengan pemotongan batang utama setinggi $10 \mathrm{~cm}$ yang akan menghasilkan anakan yang banyak. berkembang sedangkan jumlah anakan akan berkurang.

$\mathrm{J} 1$ : jarak tanam $50 \times 30 \mathrm{~cm}$

$\mathrm{J} 2$ : jarak tanam $66,6 \times 30 \mathrm{~cm}$

J3: jarak tanam 100x30 cm

\section{Pengaruh Perlakuan Jumlah Benih per Lubang dan Jarak Tanam Hijauan Sorghum terhadap Proporsi Batang dan Daun pada Ratun Ketiga}

Hasil analisis ragam pada proporsi batang dan daun menunjukkan bahwa tidak terjadi interaksi $(\mathrm{P}>0,05)$ antara perlakuan jumlah benih per lubang dan jarak tanam, perlakuan jumlah benih per lubang dan jarak tanam tidak berpengaruh nyata $(\mathrm{P}>0,05)$ terhadap proporsi batang daun hijauan sorghum pada ratun ketiga. Rata-rata proporsi batang daun hijauan sorghum pada ratun ketiga tertera pada Tabel 3.

Tabel 3 menunjukkan bahwa rata-rata perlakuan jumlah benih satu menghasilkan proporsi batang dan daun lebih banyak dibandingkan benih satu dan tiga. Menurut Jalil et al. (2015), tanaman yang ditanam satu bibit per lubang tanam memberikan hasil yang lebih tinggi, karena pada penggunaan bibit yang terlalu sedikit akan lebih baik untuk pertumbuhan tanaman karena lebih rendah persaingan dalam penyerapan unsur hara dibandingkan dengan penggunaan bibit yang terlalu banyak. Jumlah bibit yang sedikit menyebabkan tanaman lebih banyak menerima intensitas cahaya matahari sehingga aktivitas fotosintesis berlangsung lebih baik (Misran, 2014). 
Tabel 3. Rata-rata proporsi batang dan daun hijauan sorghum pada ratun ketiga

\begin{tabular}{ccccc}
\hline \multirow{2}{*}{ Perlakuan } & \multicolumn{3}{c}{ Perlakuan } & \multirow{2}{*}{ Rata-rata } \\
\cline { 2 - 4 } & B1 & B2 & B3 & \\
\hline J1 & 5,20 & 5,09 & 4,56 & $4,95 \pm 0,34$ \\
J2 & 4,89 & 4,59 & 4,82 & $4,77 \pm 0,15$ \\
J3 & 4,99 & 5,26 & 3,90 & $5,16 \pm 0,63$ \\
\hline Rata-rata & $5,13 \pm 0,21$ & $4,98 \pm 0,35$ & $4,69 \pm 0,73$ & \\
\hline
\end{tabular}

Keterangan:

Tidak berpengaruh nyata $(\mathrm{P}>0,05)$

$\mathrm{B} 1$ : benih 1 per lubang tanam

B2: benih 2 per lubang tanam

B3: benih 3 per lubang tanam

\author{
$\mathrm{J1}$ : jarak tanam $50 \times 30 \mathrm{~cm}$ \\ $\mathrm{J} 2$ : jarak tanam $66,6 \times 30 \mathrm{~cm}$ \\ J3: jarak tanam $100 \times 30 \mathrm{~cm}$
}

Pada perlakuan jarak tanam menunjukkan rata-rata proporsi batang daun tertinggi diperoleh pada perlakuan jarak tanam tiga. Menurut Guritno dan Sitompul (1995), jarak tanam yang lebar dapat memperoleh pertumbuhan yang baik, karena persaingan dalam mendapatkan unsur hara, air, dan sinar matahari diantara tanaman menjadi lebih rendah. Semakin sempit jarak tanam maka akan semakin sulit juga tanaman mendapatkan unsur hara dan cahaya matahari. Tanaman yang menerima cahaya lebih banyak cenderung memiliki jumlah daun lebih banyak.

Menurut Muyassir (2012), peningkatan kerapatan tanam per satuan luas dari satu sisi dapat meningkatkan jumlah populasi tanaman per satuan luas, sehingga dapat meningkatkan produksi tanaman tersebut. Defoliasi tanaman yang berumur relatif muda akan menghasilkan rasio yang lebih besar antara daun dan batang. Nitrogen berperan bagi pertumbuhan vegetatif tanaman (Parsons dan Sunley, 2001). Nitrogen dalam jumlah yang cukup berperan dalam mempercepat pertumbuhan tanaman secara keseluruhan, khususnya batang dan daun (Lingga, 1986)

\section{Pengaruh Perlakuan Jumlah Benih per Lubang dan Jarak Tanam Hijauan Sorghum terhadap Tinggi Tanaman pada Ratun Ketiga}

Hasil analisis ragam pada lampiran menunjukkan bahwa tidak terjadi interaksi $(\mathrm{P}>0,05)$ antara perlakuan jumlah benih per lubang dan jarak tanam. Pada perlakuan jumlah benih per lubang memberikan pengaruh nyata $(\mathrm{P}<0,05)$, sedangkan perlakuan jarak tanam tidak berpengaruh nyata $(\mathrm{P}>0,05)$ terhadap tinggi tanaman hijauan sorghum pada ratun ketiga. Rata-rata tinggi tanaman hijauan sorghum pada ratun ketiga tertera pada Tabel 4.

Tabel 4. Rata-rata tinggi tanaman hijauan sorghum pada ratun ketiga

\begin{tabular}{|c|c|c|c|c|}
\hline \multirow{2}{*}{ Perlakuan } & \multicolumn{3}{|c|}{ Perlakuan } & \multirow[t]{2}{*}{ Rata-rata } \\
\hline & B1 & B2 & B3 & \\
\hline & & -(cm)--- & & 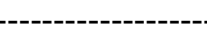 \\
\hline $\mathrm{J} 1$ & 203,50 & 201,50 & 161,44 & $188,81 \pm 23,72$ \\
\hline $\mathrm{J} 2$ & 205,33 & 194,00 & 164,89 & $188,07 \pm 20,86$ \\
\hline $\mathrm{J} 3$ & 212,67 & 191,33 & 194,72 & $199,57 \pm 11,46$ \\
\hline
\end{tabular}

Rata-rata $\quad 207,17 \pm 4,85^{\mathrm{b}} \quad 195,61 \pm 5,27^{\mathrm{a}} \quad 173,69 \pm 18,30^{\mathrm{a}}$

Keterangan:

Nilai dengan huruf superscript yang berbeda pada baris yang sama menunjukkan berbeda nyata $(\mathrm{P}<0,05)$

$\mathrm{B} 1$ : benih 1 per lubang tanam $\mathrm{J} 1$ : jarak tanam $50 \times 30 \mathrm{~cm}$

$\begin{array}{ll}\mathrm{B} 2 \text { : benih } 2 \text { per lubang tanam } & \mathrm{J} 2 \text { : jarak tanam } 66,6 \times 30 \mathrm{~cm}\end{array}$

B3: benih 3 per lubang tanam

J3: jarak tanam $100 \times 30 \mathrm{~cm}$

Perlakuan satu benih per lubang menunjukkan hasil yang tertinggi terhadap tinggi tanaman yaitu $207,17 \mathrm{~cm}$ dan hasil terendah pada perlakuan tiga benih per lubang yaitu 172,69 $\mathrm{cm}$. Hal ini diduga bahwa penggunaan satu benih tanaman tidak mengalami persaingan, sehingga tanaman dapat lebih leluasa dalam menyerap unsur hara 
sinar matahari untuk proses fotosintesis. Menurut Indrayanti (2010) menyatakan bahwa kepadatan populasi tanaman yang tinggi akan mempengaruhi pertumbuhan tanaman dan pada akhirnya penampilan tanaman secara individu akan menurun karena persaingan dalam intersepsi radiasi sinar matahari, absorbi air dan unsur hara serta pengambilan $\mathrm{CO}_{2}$ dan $\mathrm{O}_{2}$. Ditambahkan oleh Ferry (2009) bahwa pada ada umumnya makin tinggi kepadatan populasi tanaman, individu tanaman makin bersaing untuk memperebutkan cahaya, sehingga individu tanaman makin memperlihatkan gejala etiolasi.

Perlakuan jarak tanam ketiga menghasilkan tinggi tanaman tertinggi yaitu 199,57 cm. Hal tersebut menunjukkan bahwa kerapatan tanaman yang optimal dalam penangkapan cahaya untuk fotosintesis yang pada akhirnya akan mampu meningkatkan pertumbuhan tanaman. Hal tersebut sesuai pendapat Qudry et al. (2016) menyatakan bahwa pengaturan jarak tanam berpengaruh terhadap besarnya intensitas cahaya dan ketersediaan unsur hara yang dibutuhkan bagi tanaman, sehingga tanaman dapat tumbuh optimal. Jarak tanam yang lebar menyebabkan intensitas cahaya yang diterima dapat menyentuh seluruh permukaan daun dan semakin banyak ketersediaan unsur hara bagi individu tanaman.

Hasil penelitian menunjukkan bahwa rata-rata tinggi tanaman yang dihasilkan penelitan ini yaitu 173,69--207,17 cm lebih rendah dari Utami (2019) yang memperoleh tinggi tanaman berkisar 199,39--215,28 cm. Perbedaan pertumbuhan tanaman dipengaruhi oleh faktor internal dan ekternal. Faktor internal seperti gen dan hormon mempengaruhi pertumbuhan melalui sifat yang diwariskan.

Penelitian ini lebih baik dari dari Badan Penelitian dan Pengembangan Pertanian pada tahun 2001 yang telah melepas sorghum dengan varietas Numbu dengan tinggi tanaman sebesar $187 \mathrm{~cm}$ pada umur panen 100--105 hari. Varietas Numbu memiliki batang yang kecil namun tinggi. Semakin tinggi tanaman semakin tinggi pula kecenderungan untuk rebah. Varietas yang mempunyai batang yang pendek akan lebih banyak menyerap sinar matahari dibandingkan dengan penyerapan sinar matahari oleh varietas yang tinggi.

\section{Pengaruh Perlakuan Jumlah Benih per Lubang dan Jarak Tanam Hijauan Sorghum terhadap Jumlah Daun pada Ratun Ketiga}

Hasil analisis ragam menunjukkan bahwa tidak terjadi interaksi $(\mathrm{P}>0,05)$ antara perlakuan jumlah benih per lubang dan jarak tanam, perlakuan jumlah benih per lubang dan jarak tanam tidak berpengaruh nyata $(\mathrm{P}>0,05)$ terhadap jumlah daun hijauan sorghum pada ratun ketiga. Rata-rata jumlah daun hijauan sorghum pada ratun ketiga tertera pada Tabel 5.

Tabel 5. Rata-rata jumlah daun hijauan sorghum pada ratun ketiga

\begin{tabular}{ccccc}
\hline \multirow{2}{*}{ Perlakuan 2 } & \multicolumn{3}{c}{ Perlakuan 1 } & Rata-rata \\
\cline { 2 - 4 } & $\mathrm{B} 1$ & $\mathrm{~B} 2$ & $\mathrm{~B} 3$ & \\
\hline J1 & 8,33 & 8,25 & 7,56 & $8,05 \pm 0,43$ \\
J2 & 8,83 & 7,83 & 7,78 & $8,15 \pm 0,59$ \\
J3 & 8,17 & 8,33 & 8,39 & $8,30 \pm 0,12$ \\
\hline Rata-rata & $8,44 \pm 0,35$ & $8,14 \pm 0,27$ & $7,91 \pm 0,43$ & \\
\hline
\end{tabular}

Keterangan:

Tidak berpengaruh nyata $(\mathrm{P}>0,05)$

$\mathrm{B} 1$ : benih 1 per lubang tanam

B2: benih 2 per lubang tanam

B3: benih 3 per lubang tanam

$\mathrm{J} 1$ : jarak tanam $50 \times 30 \mathrm{~cm}$

$\mathrm{J} 2$ : jarak tanam $66,6 \times 30 \mathrm{~cm}$

J3: jarak tanam $100 \times 30 \mathrm{~cm}$

Jumlah daun tertinggi pada perlakuan jarak tanam $100 \times 30 \mathrm{~cm}$ dengan 1 benih meskipun tidak berbeda nyata dengan perlakuan jarak tanam $66,6 \times 30 \mathrm{~cm}$ dengan 2 benih. Perlakuan yang memberikan respon jumlah daun rendah adalah jarak tanam 50x30 $\mathrm{cm}$ dengan 3 benih. Berdasarkan pendapat Badan Penelitian dan Pengembangan 
Pertanian (2001), jumlah daun pada tanaman sorghum varietas Numbu adalah 14 helai, tetapi pada pengamatan ini jumlah daun tertinggi adalah 8 . Hal tersebut diduga karena saat pengamatan yang dilakukan, daun yang terhitung adalah daun yang masih berwarna hijau sehingga daun yang sudah mengering tidak ikut terhitung.

Penggunaan satu benih per lubang menyebabkan pertumbuhan tidak mengalami persaingan sehingga tanaman lebih leluasa dalam penyerapan unsur hara dan air selain itu didukung oleh tanaman yang tinggi sehingga penampang daun dapat menyerap sinar matahari untuk proses fotosintesis. Pada jarak tanam yang lebar tanaman sorghum mendapatkan cahaya matahari yang lebih banyak, daun mampu berfotosintesis secara optimal sehingga menghasilkan jumlah daun yang lebih banyak sedangkan pada jarak tanam yang rapat daun tanaman cenderung untuk berimpit sehingga tidak maksimal dalam menerima sinar matahari (Muyassir, 2012).

Menurut Bunyamin dan Awaluddin (2013), bahwa tanaman yang memiliki tinggi tanaman yang optimum akan diikuti dengan pertambahan jumlah daun, karena semakin tinggi tanaman semakin banyak daun yang terbentuk. Jumlah daun behubungan dengan dengan unsur hara yang yang ada dalam tanah dan diserap oleh tanaman melalui akar.

Penggunaan pupuk $\mathrm{N}$ yang diberikan dapat merangsang pertumbuhan vegetatif sorghum baik itu pertumbuhan batang, pembentukan tunas serta pembentukan daun dan akar. Hal ini sesuai dengan pernyataan Sundara (1998) yang menyatakan nitrogen merupakan unsur hara utama yang mempengaruhi hasil dan kualitas tanaman untuk pertumbuhan vegetatif, yaitu pembentukan tunas, pembentukan daun, pertumbuhan batang, dan pertumbuhan akar. Peningkatan pupuk $\mathrm{N}$ dapat meningkatkan jumlah daun.

\section{SIMPULAN DAN SARAN}

\section{Simpulan}

Berdasarkan penelitian yang sudah dilakukan dapat diambil kesimpulan sebagai berikut :

1. tidak terdapat interaksi $(\mathrm{P}>0,05)$ antara jumlah benih per lubang dan jarak tanam terhadap produksi segar, jumlah anakan, proporsi batang daun, tinggi tanaman, dan jumlah daun hijauan sorghum pada ratun ketiga;

2. perlakuan jumlah benih per lubang berpengaruh nyata terhadap tinggi tanaman, namun tidak berpengaruh nyata terhadap produksi segar, jumlah anakan, proporsi batang daun, dan jumlah daun hijauan sorghum pada ratun ketiga;

3. perlakuan jarak tanam tidak berpengaruh nyata terhadap produksi segar, produksi bahan kering, jumlah anakan, proporsi batang daun, tinggi tanaman, jumlah daun, dan lebar daun hijauan sorghum pada ratun ketiga

\section{Saran}

Berdasarkan penelitian yang telah dilakukan, penulis memberikan saran sebagai berikut:

1. pemeliharaan yang baik pada budidaya ratun dapat meningkatkan hasil produksi tanaman sorghum.

2. perlu dilakukan penelitian lebih lanjut tentang jumlah benih per lubang dan jarak tanam terhadap produksi segar, jumlah anakan, proporsi batang daun, tinggi tanaman, dan jumlah daun tanaman sorghum pada ratun ketiga.

\section{DAFTAR PUSTAKA}

Bunyamin, Z. dan Awaluddin. 2013. Pengaruh Populasi Tanaman Terhadap Pertumbuhan dan Produksi Jagung Semi/Baby Corn. Balai Penelitian Tanaman Serelia. Fakultas Pertanian Universitas Hassanudin. Makasar. 233 halaman.

Escalada, R. G. and D. L. Plucknett. 1975. Ratoon cropping of sorghum: II. effect of daylength and temperature on tillering and plant development. Journal of Agronomy 67 (4): 479-484.

Ferry, F., M. Tino, dan Akyas. 2009. Pengaruh umur pindah tanam dan populasi tanaman terhadap hasil dan kualitas sayuran pakcoy (Brassica campestris L., Chinensis group) yang ditanam dalam naungan kasa di dataran medium. Bandung. Jurnal Agrikultura 20 (3): 216--224.

Guritno dan S. M. Sitompul. 1995. Analisis Pertumbuhan Tanaman. Gajah Mada. Yogyakarta.

Harjadi, S. S. 2002. Pengantar Agronomi. PT Gramedia Pustaka Utama. Jakarta. 
Harrel, D. L., A. B. Jason, and B. Sterling. 2009. Evaluation of main-crop stubble height on ratoon rice growth and development. Field Crop. Res. 114: 396--403.

Husna, Y. dan Ardian. 2010. Pengaruh penggunaan jarak tanam terhadap pertumbuhan dan produksi padi sawah (Oryza sativa L.) varietas IR 42 dengan metode SRI (System of Rice Intensification). Jurnal SAGU 9 (1): 21--27.

Indrayanti, A. L. 2010. Pengaruh Jarak Tanam dan Jumlah Benih Terhadap Pertumbuhan Vegetatif Jagung Muda. Skripsi. Fakultas Pertanian. Unversitas PGRI Palangkaraya. Palangkaraya.

Irfan, M. 1999. Respons Tanaman Jagung (Zea mays L.) Terhadap Pengelolaan Tanah dan Kerapatan Tanam Pada Tanah Andisol. Tesis. Program Pasca Sarjana USU. Medan.

Jalil, M., D. Nurba, dan I. Subandar. 2015. Pengaruh umur pindah tanam dan jumlah bibit per lubang tanam terhadap pertumbuhan dan produksi padi (Oryza sativa L.). Jurnal Agrotek Lestari 1 (1): 55--65.

Lestari, U. 2019. Pengaruh Jumlah Benih per Lubang dan Jarak Tanam Hijauan Sorgum Manis (Sorghum bicolor (L.) Moench) terhadap Produksi Segar, Produksi Bahan Kering, Jumlah Anakan, dan Proporsi Batang Daun. Skripsi. Universitas lampung. Lampung.

Lingga. 1986. Petunjuk Penggunaan Pupuk. Penebar Swadaya. Jakarta

Masdar, M. Karim, B. Rusman, N. Hakim, dan Helmi. 2006. Tingkat hasil dan komponen hasil sistem intensifikasi padi (SRI) tanpa pupuk organik didaerah curah hujan tinggi. Jurnal Ilmu Pertanian 8 (2): 126--131.

Misran. 2014. Efisiensi Penggunaan jumlah bibit terhadap pertumbuhan dan produksi padi sawah. Jurnal Pertanian Terapan 14 (1): 39--47.
Muyassir. 2012. Efek jarak tanam, umur, dan jumlah bibit terhadap hasil padi sawah (Oryza Sativa L.). Jurnal Manajemen Sumber Daya Lahan 1 (2): 07--212.

Parsons R. dan R. J. Sunley . 2001. Nitrogen nutrition andthe role of root-shoot nitrogen signalling particularly in symbiotic system. Journal of Experimental Botany 52 (1): 435-443.

Puspita, N., Dody Kastono, dan Siyanto. 2012. Pertumbuhan dan hasil Sorghum Manis (Sorghum bicolor (L.) Moench) tanam baru dan ratoon pada jarak tanam berbeda. Fakultas Pertanian Gadjah Mada. Jurnal Budidaya Pertanian 1 (4) : 2622-7452.

Setyati, S. 2002. Pengantar Dasar Agronomi. Gramedia. Jakarta

Sundara, B. 1998. Sugarcane Cultivation. First Edition. Vikas Publishing House Pvt Ltd, New Delhi. 292.

Qudry, A. AI., Irsal, dan Revandi, I.M. Damanik. 2016. Pengaruh jarak tanam dan dosis pupuk nitrogen terhadap pertumbuhan Bud Chip Tebu (Saccharum Officinarum L.). Jurnal Agroteknologi 4 (4): 23376597.

Tambunan, S., P. Marbun, dan E. Harahap. 2018. Pengaruh jumlah bibit dan sistem tanam jajar legowo yang dimodifikasi terhadap pertumbuhan dan produksi padi sawah (Oryza Sativa L.) di Kecamatan Medan Tuntungan. Jurnal Agroteknologi FP USU 6 (3): 2337--6597.

Utami, M. N. 2019. Pengaruh Jumlah Benih per Lubang dan Jarak Tanam Sorghum Manis (Sorghum bicolor (L.) Moench) terhadap Tampilan Produksi pada Pemotongan Kedua. Skripsi. Jurusan Peternakan. Fakultas Pertanian. Universitas Lampung. Bandar Lampung. 